\title{
Ensuring Food Hygiene and Safety in Ghana: a Legal Perspective
}

\author{
Agbezuge Sylvester (Rev. Fr) \\ Barrister at Law/ Lecturer \\ Multidisciplinary Studies Department \\ Ho Technical University \\ Ghana
}

\begin{abstract}
Food safety is a scientific discipline describing handling, preparation and storage of food in ways that prevent food borne illness. It includes a number of routines that should be followed to avoid potentially severe health hazards. There are a number of legislations in Ghana which are formulated to ensure consumer protection and safety in relation to food products. However, recent sanitation and health challenges facing the nation imply that the relevant legislations on the subject are either not being enforced or that people are ignorant of them.This paper outlines and discusses the general legislative framework of food hygiene and food safety in Ghana. It also explains specific legislations which regulate each aspect of the chain of food production and offers some useful suggestions with regard to the implementation and enforcement of the relevant legislations designed to ensure food hygiene, consumer protection and safety in Ghana.
\end{abstract}

\section{Introduction}

Food is one of the elements essential for growth and development to humans as well as animals. However, if this important ingredient of growth is not handled well, it may turn out to affect human health. It is therefore important that food that is consumed by human beings is safe in all respects. Food safety is a scientific discipline which describes food handling, preparation and storage in ways that prevent food borne illness. Each of these processes is governed by regulations which are discussed in this paper to demonstrate that food hygiene and safety can be attained only when the relevant legislations on the subject are enforced. Additionally, some useful suggestions are also offered as regards food hygiene and safety in Ghana.

Keywords: Food, Hygiene, Regulation, Safety.

\section{Literature Review}

\section{International food Safety regulations}

The production, processing, distribution, retail, packaging and labeling of food stuffs are governed by a mass of laws, regulations, codes, practice and guidelines. In wales and Northern Ireland, the food Standard Agency works closely with local authority enforcement officers to make sure food law is applied throughout the food chain.

The current code of Practice for England came into force on $7^{\text {th }}$ April, 2015. The law makes provisions for arrangements for food joint establishments, their registration, and inspection of mobile food establishments in vehicles, ships and aircrafts.

In Scotland, the Food Law Code of Practice, 2015 came into force across Scotland on $1^{\text {st }}$ April, 2015 and replaced any existing version of the Code. The Code of Practice sets out instructions and criteria to which the local authority (Food and Feed Authority) should have regard when engaged in the enforcement of food and feed law. The Code of Practice sets out standards required of those who process distribute or sell food products.

In Australia, Food Standards Australia requires all food businesses to implement food safety systems. These systems are designed to ensure that food is safe to consume so that the increasing incidence of food poisoning may minimize. They include basic food safety training for at least one person in each business. Food Safety and requirements are set out at the national level in the Food Standards Code, and brought into force in state by statebased Acts and Regulations. Legislation means that people responsible for selling or serving unsafe food may be liable for heavy fines. 
The Parliament of the European Union (EU) often makes legislations on food safety in the form of directives and regulations, many of which are mandatory for member states and which therefore must be incorporated into individual's countries' national legislation. Individual member states may also have other legislations and controls in respect of food safety, provided that they do not prevent trade with other states and can differ considerably in their internal structure and approaches to the regulation and control of food safety.

These laws are to ensure that food is safe for human and animal consumption.

\section{Food Hygiene and Safety Regulations in Ghana}

The legal regime of food hygiene and safety in Ghana is a blend of common law, statutes, bye-laws and other regulations. Some of the key legislations are discussed below.

\subsection{The English Common Law Position on Food Safety}

The classical common law stance on defective or harmful products or goods was 'caveat emptor' (buyer beware). Under the principle of law, the individual buying goods was expected to take steps to ensure that the goods were safe for use. If he failed to protect himself, any loss would be where it fell with him.

In 1893 however, the English Parliament intervened to give protection to purchasers of goods via the Sale of Goods Act where conditions were implied into the Act to the effect that goods sold are to be fit for consumption. Where goods had been bought by the person to whom they occasioned loss or injury, the burden of liability shifted to the retailer.

It was however discovered that this legislation offered comfort only to purchasers of goods and not to the ultimate consumer who might not be the buyer. For instance, a person suffering food poisoning from contaminated tinned fish bought for him by someone else was not assisted by the law as he could not directly take an action against the seller or manufacturer.

In 1932 however, in Donoghue v Stevenson[1932] AC 562; [1932] ALL ER 1 HL, Donoghue drank a bottle of ginger beer, manufactured by Stevenson, which a friend bought from a retailer and gave to her. The bottle allegedly contained the decomposed remains of a snail which were not, and could not be detected (as the bottle was opaque) until the greater part of the content of the bottle was consumed. She alleged that she fell ill as a result and sued Stevenson.

The House of Lords held that the ultimate user of a product causing injury to him may have an action in negligence against the manufacturers of the product.

To solidify the principle of the duty of care owed by manufactures of products including food towards their ultimate consumers, the UK government responded by enacting the Consumer Protection Act of 1987.

It is important to note that the duty of care principle derived from Donoghuev Stevenson is applicable in our justice delivery system because common law principles are applicable in Ghana as provided for under article 11 (1) (e) of the Constitution of Ghana, 1992.

Thus, in Aboagye v KumasiBreweryLtd [1964] GLR 242, the plaintiff was drinking beer with some friends when he found a rotten palm nut in the beer bottle after consuming about three-quarters of the contents of the beer bottle. During the night, he vomited and had frequent stools. The following morning he saw a doctor who diagnosed the vomiting and diarrhea as resulting from food poisoning.

Consequently, he brought an action against the defendant-manufacturers claiming damages for the injury suffered by him as a result of taking the bottle of beer negligently bottled by the defendant. The defendant denied the allegation and claimed to have a full-proof system.

The High Court held that on the evidence, the palm-nut was found in the bottle of the star beer manufactured by the defendant from which the plaintiff drunk. The fact that the nut was found in the bottle raised the legal maxim of resipsa loquitur (the matter is self-explanatory) and presumed the negligence of the manufacturers in the preparation of the beer.

It is important to note that the common law principle on negligence is applicable to manufacturers of food products such as canned foods, tin fish, tin food, baked beans, packaged food and similar food products in Ghana. Any manufacturer of any of the above food products and similar ones, who negligently sells or distributes contaminated food products to the consuming public, may be liable in damages to those consumers and potential consumers. 


\subsection{Public Health Act, 2012 (Act 851)}

The Act legislates the various stages of food processing before it finally gets to the consumer. Areas of legislation include: Manufacturing, Packaging, distribution or sale.

\subsubsection{Manufacturing}

It is mandatory for manufacturers of food or food products to have the food or the products registered by the Food and Drugs Authority.

This is aimed at ensuring that the food in question complies with the prescribed standards and the manufacturing operations. (s.97 Act 851). The law applies to those who export and import food as well. They are mandated to register with the Food and Drugs Authority before carrying out their trade.

The above provisions are applicable to those who manufacturer food that are already packaged in cans and tins or those who import or export such foods.

Section 106 of Act 851 provides that those who prepare or manufacturer food for sale (food vendors) are to be supervised by a person with appropriate knowledge and qualification who can ensure the purity, quality and whole someness of the food. This responsibility is assigned to the Health Department of Metropolitan, Municipal and District Assemblies.

Section 52 of Act 851 makes it an offence punishable by a fine or imprisonment for not more than four years for anybody who prepares, packages, conveys or stores or displays for sale, food under insanitary conditions to the public.

\subsubsection{Packaging:}

Food packaging has a lot of health implications. As such, it must be done carefully and appropriately to avoid contamination which would eventually affect the health of consumers.

Sections 52(1), 100(5) 103(1) and 104 of Act 851 make it mandatory for all those who either package or process food for sale to comply with safety standards. It is prohibited to package or process food under insanitary conditions and sell same to the public. (s.52) (Act 851). Failure to comply amounts to an offence punishable by a fine or a term of imprisonment not more than four years. Section 103(1) goes on further to make it an offence to package a food in a manner that is false, misleading, deceptive or misbranded as regards its character, nature, value additives, substance, quality, quantity, composition, merit or safety.

Any food manufacturer whose packaging is associated with any of the above descriptions commits a criminal offence and when convicted would be fined or imprisoned.

\subsection{Sale and Distribution}

The final stage of food chain is its sale or distribution to consumers or potential consumers. This stage is critical because when unwholesome food is consumed, it's impart on the consumer's health is enormous.

Section 51 of Act 851 mandates food sellers or distributors to ensure that their products are wholesome or are fit for human and animal consumption. Failure by any seller to comply with this mandatory provision amounts to a criminal offence and those prosecuted, found guilty and are convicted may be fined or imprisoned not more than four years or both.

Section 52 of the same law also prohibits the sale of food under insanitary condition. This implies that food must not be sold near refuse dumps, toilets, filthy and open drains etc. It is an offence to sell food in the above or similar conditions and anybody found culpable may be liable for imprisonment or a fine or both.

It is equally an offence under section 53 of the Act to sell, offer or expose for sale or have in possession for sale food intended for human consumption but which is unfit for human or animal consumption. Anybody who engages in any of the above mentioned activities would be punished accordingly.

Section 105 of Act 851 also prohibits sale of food that is not of the nature, substance, safety or quality of the article demanded by the purchaser. In other words, it is an offence under the Act to sell food that is of poor quality to the public or consumers. 


\subsection{Enforcement of Food Hygiene and Safety Regulations in Ghana}

Article 21(4) (c) of the 1992 Constitution, guarantees every Ghanaian the right to health and safety in all circumstances. One of the major components of health and safety is food hygiene and safety. This is because whatever we consume as food determines to a large extent our health.

To ensure food safety and hygiene some state institutions have been mandated to enforce food hygiene and safety regulations in Ghana. They include: the Food and Drugs Authority, the Health Department of Metropolitan, Municipal and District Assemblies as well as the Police Service.

\subsection{The Food and Drugs Authority}

The Food and Drugs Authority of Ghana was established under Part Seven, section 80 of the Public Health Act, 2012 (Act 851). Section 81 of the Act states the object of the Authority as to provide and enforce standards for the sale of food, herbal medicinal products, cosmetics, drugs, medicinal devices and household chemical substances.

Section 82 (b) and (c) provide among other things that to achieve its objects, the Food and Drugs Authority is expected to ensure adequate and effective standards for food and other commodities and monitor through the District Assemblies and any other agency of state compliance with the provisions of the law on food safety standards and other related matters.

The law therefore empowers, the Authority to monitor food manufacturing or preparation, packaging and sale in order to ensure compliance with law.

The commonest source of food in Ghana is street food - food readily available along the streets in every village, town for sale which is patronized by a lot of Ghanaians. It is the duty of the Food and Drugs Authority to monitor activities of these vendors to ensure compliance with safety standards. The Authority does so either by its officers or by other state agencies such as the District Assemblies as by law requires.

\subsection{Health Department of District Assemblies}

The Second Schedule and section 14 of the Local Governance Act, 2016 (Act 936) provides for the establishment of Health Departments in every Metropolitan, Municipal and District Assemblies in Ghana. These departments are to ensure food safety and other related matters in the country.

They are to enforce food hygiene and safety regulations provided for under the Public Health Act of 2012 in collaboration with the Food and Drugs Authority (s. 82(b), Act 851.

They are expected to carry out this responsibility by identifying and registering all food vendors under their jurisdiction as well as monitor their activities with regard to food preparation, packaging and selling. Officers from the Health Department are mandated by law to enter any premises where food is being prepared for sale and inspect it. When they discover a breach of food safety regulation, they are expected to caution, have the license given to the vendor seized or send the offender to court for prosecution.

\subsection{The Ghana Police Service}

Another state agency responsible for the enforcement of food hygiene and safety regulations in Ghana is the Police Service.

Generally, the Ghana Police Service is responsible for the enforcement of criminal offences in Ghana. Enforcement of food safety regulations falls under their purview because section 286 of the Criminal Offences Act, 1960 (Act 29) and Parts Five and Seven of the Public Health Act, 2012 (Act 851) make the preparation and sale of unwholesome and substandard food a criminal offence.

It is therefore the responsibility of the Police to arrest and prosecute food vendors who violate food safety regulations in Ghana.

\subsection{Law Enforcement and Challenges}

From the discussion so far, it is evident that Ghana has a beautiful legal regime on food hygiene and safety. However, as typical of Africa in general and Ghana in particular, these laws are hardly enforced. One would ask: How many food vendors in Ghana are registered? How many are monitored by the appropriate authorities? How many defaulters are prosecuted? The fact is that hardly is any of the above carried out.

Come as it may, one cannot ignore the fact that, just as every human activity has its own challenges so it is with the enforcement of food safety laws in Ghana. A number of factors account for this phenomena. 


\subsection{Growing Population}

Whenever population explodes law enforcement also becomes difficult. No wonder as Ghana's population grows it has become more difficult to enforce food safety laws. The most affected are urban habitations in the country.

\subsection{Failure to Enforce Laws}

One of the greatest weaknesses of Ghana as a nation is failure to enforce our laws. Even though state institutions have been mandated by law to enforce food safety laws they hardly enforce them thereby putting lives of consumers at risk.

\subsection{Bribery by Food Vendors}

In instances where law enforcement agencies go out to enforce food safety laws, they are faced at times with the temptation of bribes being offered them by food vendors who fail to compromise their duties consequently put lives of consumers at risk.

comply with regulations. Those who

\subsection{Lack of Education}

Even though some education on food safety is done on both the print and electronic media, I believe this is not enough as many people do not listen to those educative programmes. A lot of vendors as a result violate food safety laws in ignorance while the impact is felt by the equally ignorant consuming public.

\section{Recommendations}

Since unsafe food can lead to disease and even death, I recommend that state institutions tasked to enforce food safety laws should be up and doing in the discharge of their duties.

The Town Council System in the 1970s and the 1980s ensured that food safety and environmental hygiene laws were well enforced due to the commitment of the officers involved. The same should be done by the Food and Drugs Authority, the Health Departments of the District Assemblies and the Police to avert perennial outbreak of cholera and other food borne diseases in the country.

\section{Conclusion}

Human being cannot live without food. But one becomes healthy or sick depending on the sort of food we consumes. Enforcement of food safety laws is therefore a shared responsibility. Food vendors and manufacturers must ensure compliance with law. Law enforcers must be responsible and the consuming public must avoid patronizing food that are not hygienically prepared or are sold in insanitary environments. They must also report unwholesome food vendors to the law enforcement agencies for quick action.

\section{References}

Aboagye v Kumasi Brewery Ltd [1964] GLR 242

Brazier M. and Murphy J. (1999).Street on Torts $10^{\text {th }}$ edn. Butterworths, London, UK

Constitution of Ghana, 1992

Donoghue (or M'Alister) v Stevenson [1932] ALL ER 1

Food Standards Agency - Enforcement Regulations www.food.gov.uk - (accessed 27 April, 2017)

Local Governance Act, 2016 (Act 936)

Mensah-Bonsu J.A.N. (1999). The Annotated Criminal Code of Ghana, $3^{\text {rd }}$ edn. Black Mask Ltd, Accra.

Public Health Act, 2012 (Act 851) 